УДК 378.147:7.071.1:7.012

DOI:

Жанна Ясеницька, старший викладач кафедри культурології та мистецької освіти Дрогобицького державного педагогічного університету імені Івана Франка

Галина Савчин, старший викладач кафедри культурології та мистецьької освіти Дрогобииького державного педагогічного університету імені Івана Франка

\title{
ОСНОВИ ДИЗАЙНУ В ЗМІСТІ ПІДГОТОВКИ ХУДОЖНИКА-ПЕДАГОГА
}

У статті окреслено проблему становлення та розвитку дизайн-освіти в Украйні, розкрито значення дизайну в сучасному культурологічному просторі та освітньому процесі, висвітлено роль, місие та актуальність впровадження основ дизайну в змісті підготовки майбутніх художників-педагогів, акцентовано значимість професійного становлення художника-педагога з метою реалізаиії основ дизайнерської освіти у прочесі безперервного навчання. Впровадження дизайну як напрямку підготовки майбутніх художниківпедагогів у закладах вищої освіти потребує теоретичного осмислення і практичної реалізації, адже дизайн як засіб формування проектної художньо-естетичної культури, національної самосвідомості майбутніх фахівців має стати складовою їхньої професійної підготовки.

Ключові слова: вища освіта; мистецька освіта; дизайн-освіта; художник-педагог; художня культура; духовна культура; дизайн.

Jim. 9.

Zhanna Yasenytska, Senior Lecturer of the Culturology and Art Education Department Drohobych Ivan Franko State Pedagogical University

Halyna Savchyn, Senior Lecturer of the Culturology and Art Education Department Drohobych Ivan Franko State Pedagogical University

\section{BASIS OF DESIGN IN CONTENT OF PREPARATION OF ARTIST OF PEDAGOGUE}

The article outlines the problem of the formation and development of design education in Ukraine, reveals the importance of design in the contemporary cultural space, highlights the role, place and relevance of the implementation of the foundations of design in the content of the training of future artists-teachers, emphasizes the importance of training the artist-teacher in order to implement the foundations of design education in the process of continuous learning. The design is considered as a specific type of aesthetic activity associated with cultural, sociocultural and personal transformations. The regularities of the process of structural changes in the system of education in the modern Ukrainian society, the theoretical and methodological and conceptual foundations of the use of the system of design education at different levels of the educational process are revealed.

The article covers the actual design problems as one of the types of creative artistic and design activities, which is based on the cultural and artistic principles of fine arts and decorative arts and the latest design technologies, has unlimited educational and creative development opportunities. Artistic and pedagogical education provides the opportunity to prepare specialists in the direction of modern design, synthesis of educational artistic and pedagogical disciplines directed at realization of contemporary cultural and artistic demands of society. In contemporary art there is a large number of specialties of design, united by its three main branches - industrial design, graphic design, environment design, as well as specialized areas: interior design, industrial design, decorative design, ethno design. Education of design is a time consuming process and this trend will continue in the 21 st century. The introduction of design as a direction of the training of future artist-educators in higher education institutions requires theoretical reflection and practical implementation, since design is considered as a means of forming the design art-aesthetic culture, national consciousness of future specialists should become an integral part of their professional training.

Keywords: a higher education; an artistic education; a design education; an artist-teacher; an art culture; a spiritual culture; a design.

П остановка проблеми. Художникдизайнер працює для величезного кола споживачів, репрезентує та практично втілює власні мистецькі проекти у різні сфери життя: побут, відпочинок, промисловість тощо. Звідси виникає потреба формування у “споживача" естетичних цінностей дизайнерської роботи, адже митець творить для глядача. Отже, постає актуальна потреба підготовки художниківпедагогів, котрі володіють основами дизайну. Змістом їх подальшої професійної сфери діяльності, пріоритетним напрямом виступає навчання та виховання молоді, котра буде цінувати і використовувати дизайнерський арсенал у різних сферах сучасного життя.

Мистецтво дизайну, як домінуючий напрям 


\section{ОСНОВИ ДИЗАЙНУ В ЗМІСТІПДГОТОВКИ ХУДОЖНИКА-ПЕДАГОГА}

формування естетичного, мистецького, полікультурного світогляду юної особистості одна 3 найважливіших сфер сучасної художньої культури. Дизайн, у всіх своїх багатогазулевих проявах - це специфічна форма художнього відображення й пізнання світу. Мистецтво дизайну поєднує споживацькі та естетичні якості предметів і об'єктів, призначених для безпосереднього використання людиною, $з$ їх оптимальною структурою, технологією виготовлення, активно впливають на вирішення таких проблем як функціонування виробництва й споживання, комфортне існування людей у предметному середовищі, відображає матеріальну й духовну діяльність людини, політичні, економічні, соціальні та науково-технічні умови цієї діяльності $[2,80]$.

Дизайн сьогодні - це невід'ємна частина розвитку суспільства XXI століття, а також одна 3 найважливіших сфер сучасної художньої культури, яка, безперечно, є необхідною для забезпечення життєдіяльності людини, відображення іiі духовних і матеріальних потреб, зокрема, спонукає до створення нових форм, образів та просторів, розвиває та підносить саму суб'єктивність особистості, естетизує та покращує різні сфери людської діяльності $[9,86]$. Тож і професійна підготовка майбутніх фахівців 3 дизайну та художників-педагогів, котрі формують споживчі та естетичні духовно-матеріальні цінності мистецтва та орієнтири в сучасному соціокультурному просторі, повинна охоплювати ряд навчальних дисциплін, котрі формують не тільки дизайнера у певній галузі, а й педагога, котрий сформує мистецьку особистість для “споживання”, використання дизайну у всіх необхідних життєвих та мистецьких потребах сучасної людини.

Мета статті - висвітлення актуальної проблеми розуміння дизайну в аспекті мистецтва, художньої культури та “споживання" дизайнерської “продукції” на сучасному етапі розвитку та євроінтеграції України.

Аналіз останніх досліджень і публікацій. Дослідження проблеми дизайну у змісті підготовки художника педагога є складовою частиною науково-дослідної теми кафедри культурології та мистецької освіти Дрогобицького ДПУ імені Івана Франка "Українська художня культура 20 - 21 ст. в мистецько-освітньому просторі". Зокрема, працюючи над темою “Дизайн як складова художньої культури”, вивчено та проаналізовано сучасні напрацювання науковців з порушеної проблеми.

Питання розвитку та становлення дизайн- освіти в останні десятиріччя розглядали мистецтвознавці та науковці різних сфер сучасного культурологічного процесу, зокрема питання історичного і сучасного досвіду освіти дизайнерів в Україні та за кордоном досліджували Є. Антонович, В. Глазичев, І. Голод, Г. Гребенюк, В. Даниленко, С. Лазарєв, С. Мигаль, В. Радкевич, В. Сидоренко, П. Татіївський, В. Тименко, О. Фурса, О. Хмельовський, А. Чебикін, В. Шимко, М. Яковлєв, В. Аронов, О. Боднар, О. Бойчук та інші.

Час показав, що дизайн як художньо-творча i наукова галузь потребує дослідження ролі всіх його видів у сучасному культурному просторі України, яка прагне зайняти свою нішу в світовому культурному просторі $[4,82]$.

Аналізування інформаційних джерел виявило, що питання підготовки дизайнера як викладача недостатньо напрацьовано та висвітлено у наукових дослідженнях. Окремі аспекти освіти фахівців-дизайнерів у художньо-педагогічному напрямі частково презентовані у низці публікацій вітчизняних учених (Є. Антонович, О. Боднар, М. Близнюк, С. Денисенко, І. Нагаєва, В. Прусак, В. Сидоренко, А. Терешкун, Б. Тимків, А. Шпільчак, О. Фурса, В. Яблонський, А. Шевченко та ін.). Теоретичні основи мистецької, дизайнерської i, зокрема, художньо-педагогічної освіти висвітлені в працях Г. Гребенюка, В. Даниленка, О. Олексюк, О. Отич, В. Прусака, О. Рудницької, В. Тименка та ін.

Однак, питанню наповненості змісту та підвищення якості професійної педагогічної освіти майбутніх художників-педагогів, дизайнерів приділено недостатньо уваги. Ця проблема потребує наукового дослідження і саме важливе - реалізації на практиці в освітній та мистецькій галузях.

Виклад основного матеріалу. Зміст сучасної художньої освіти в Україні одна найбільш обговорюваних проблем в колі педагогів та мистецтвознавців. 3 плином часу педагогічна освіта потребує синтезу мистецьких дисциплін, котрі допоможуть готувати викладача, здатного працювати за потребами мистецького середовища, виховувати на навчати молодь у руслі естетико-культурологічних потреб сьогодення.

Розглядаючи доволі складні протиріччя, що виникають у навчальному процесі мистецьких закладів, слід вказати та виокремити специфіку художньо-педагогічної освіти. Важлива сторона практики навчання - це формування сучасного фахівця у сфері образотворчого мистецтва, педагога, котрий здатний виховувати естетично розвинену юну особистість з урахуванням 
мистецьких потреб у найрізноманітніших сферах діяльності $[1,82]$.

Художньо-педагогічній освіті в Україні відведений особливий статус. Саме через неї реалізується державна політика, спрямована на формування інтелекту нації, розвиток науки і техніки, збереження і примноження культурної спадщини. Вона є однією 3 найскладніших та специфічних сфер людської діяльності [6, 79-80].

В останні десятиріччя в мистецьку освіту увійшов дизайн. Коло діяльності дизайну набуває усе більшого розмаїття, торкається усіх сфер життя в сучасному соціокультурному просторі. Люди найрізноманітніших професій починають називати себе дизайнерами. Декоратори перетворилися у дизайнерів інтер'єрів, садівники - у ландшафтних дизайнерів $[6,81]$. Ми ведемо мову про індустріальний та графічний дизайн, фітодизайн і фотодизайн, вебдизайн, коучинг (управлінський дизайн) тощо.

Професія дизайнера набуває все більшої популярності й затребуваності. Ця тенденція зростала протягом усього минулого століття, що вимагає аналізу ситуації як з точки зору історії цього виду діяльності новітнього часу, так і 3 огляду на майбутнє дизайну [3, $61-64]$.

Сучасний дизайн - творча діяльність людей різних професій та сфер зайнятості, проте, об'єднаних спільною, навіть глобальною метою - створення гармонійних якостей предметнопросторового середовища життєдіяльності людини та цілісного предметного світу. Дизайнерська художньо-виробнича робота у сукупності всіх іiї видів та форм пронизує різні сфери людської діяльності, естетизує їх, спонукає до створення нових форм, образів та просторів, розвиває та підносить саму суб'єктивність особистості.

Так, дизайн на теренах України рік за роком формується, вдосконалюється та виокремлюється в одну 3 найвпливовіших сучасних мистецьких галузей. За плином часу споживча функція дизайну стрімко зросла, що в свою чергу потребує як кваліфікованого дизайнера, так і естетично сформованого споживача. Саме художньопедагогічній освіті відведена пріоритетна функція - підготувати, сформувати фахівця, котрий володіє основами сучасної дизайнерської роботи та художника-педагога, котрий буде навчати та формувати культуру та естетику сучасного споживача у процесі безперервного навчання починаючи 3 дошкільного віку дитини. 3 огляду на таку проблему, сучасний педагог у сфері художньої образотворчої діяльності, повинен володіти знаннями та уміннями з основ дизайну, специфікою різноманітних напрямів дизайнерської роботи, формувати естетику світосприйняття, орієнтири у мистецькому просторі сьогодення [7].

Таке скерування підготовки художникапедагога вимагає внесення у зміст професійної освіти навчальні дисципліни, що дають можливість сформуватися фахівцю як дизайнеру та оволодіти методикою навчання основ дизайну для майбутньої педагогічної та творчої діяльності. Адже саме педагог повинен виховати та сформувати “споживача" культурних та мистецьких цінностей.

Важливе значення в процесі опанування основами дизайну у всіх його напрямах відведено композиції, технічній естетиці, художньому проектуванню, конструюванню, моделюванню та технології матеріалів. Саме ці навчальні дисципліни формують базу для дизайнерської роботи у всіх її проявах. Доцільно зазначити, що новітні напрями сучасного дизайну вимагають знання та вміння інноваційних технологій зображальної та проектної діяльності. Графічний та комп'ютерний дизайн вимагає професійного володіння мультимедійними засобами. Безперечно, що базовими навчальними дисциплінами залишаються композиція, кольорознавство, рисунок, живопис. Подальше розгалуження дизайнерської роботи за більш вузькими напрямами вимагає професійної обізнаності в інших сферах. До приклаладу: етнодизайн опирається на багатовікову історію художньої культури, ремісництво, народне та професійне декоративно-прикладне мистецтво, фольклор, релігію тощо.

Дизайн набуває особливого соціокультурного значення. Сучасний фахівець 3 дизайну повинен мати широкий світогляд, високий інтелектуальний потенціал і рівень культури, здатність до самовдосконалення, вміння творчо підходити до вирішення проблем та обирати оптимальні варіанти рішень, здатність до аналізу, вміння орієнтуватись в умовах швидко змінюваних дизайнтенденцій ринкового середовища [8, 112 - 114].

Порушена проблема вимагає практичної реалізації у навчальному процесі художньопедагогічних спеціальностей, необхідно внести, долучити у зміст навчально-виховного процесу дисципліни, котрі формують дизайнера-педагога iз урахування сучасних інноваційних процесів та вимог естетики середовища $[6,81]$. Адже, відмітною рисою часу $є$ затребуваність роботи дизайнера й на вітчизняному ринку праці, проте розвиток дизайн-освіти не розглядається в Україні як необхідна складова загальної багатоступеневої освіти. Існує певна необхідність перегляду 
концепції освіти загалом, що суттєво розширює $\mathrm{i}$ поглиблює розуміння сутності дизайнута вимагає створення державної програми розвитку цієї дисципліни.

Сучасний дизайн доцільно розглядати як цілісну систему мислення і саме тому велика відповідальність відводиться педагогу, котрий повинен сформувати сучасного “споживача" i поціновувача мистецьких творів, гармонійного предметного середовища тощо.

Дизайн потрібно розглядати як складову системи загальної освіти саме через те, що він максимально охоплює функціональні методи пізнання у будь-якій діяльності і є потужним інструментом інтелектуального розвитку. Тому на цьому етапі впровадження дизайн-освіти в Україні доцільно використовувати заняття 3 образотворчого мистецтва як формуреалізації цієї проблеми. Формування естетичних творчих якостей та вмінь у процесі художньо-педагогічної освіти має за мету розвиток творчих здібностей та естетичних потреб шляхом набуття практичних умінь у процесі навчальної творчої роботи на заняттях 3 художніх дисциплін. Важливий напрямок художньо-педагогічної освіти пов'язаний 3 питаннями виховного характеру і вимагає формування творчих якостей особистості, зокрема, творчого складу мислення $[8,120]$.

Сучасне суспільство потребує підготовки конкурентоспроможного випускника, готового до роботи в умовах конкуренції на ринку праці в Україні та враховуючи нові зарубіжні тенденції, від якого залежить економічна могутність держави та добробут нації. Необхідна подальша розробка змісту українського дизайну, організаційних форм його реалізації. Важливо продумати й експериментально апробувати методичнопроцесуальне забезпечення дизайносвітнього процесу, а також сприятливе предметнорозвивальне середовище у професійних закладах дизайн-освіти та художньо-педагогічного спрямування. Все це ефективні педагогічні умови, які $є$ необхідними й достатніми для формування сучасних українських дизайнерів в освітній сфері.

Висновки. Сучасний процес навчання та виховання, реалії сьогодення потребують професійної підготовки студентів вищих мистецьких та педагогічних навчальних закладів, творчі якості яких необхідно розкривати саме в процесі навчально-виховної діяльності на засадах різногалузевого дизайну.

Активізація дизайнерської освіти є потребою часу і ця тенденція продовжуватиметься у XXI столітті, роблячи свій непосильний внесок у культуру суспільства України. Упровадження дизайну як напрямку підготовки майбутніх художників-педагогів у 3 ВО потребує теоретичного осмислення і практичної реалізації. Дизайн як засіб формування проектної художньоестетичної культури, національної самосвідомості майбутніх фахівців має стати складовою їхньої професійної підготовки. Саме дизайн у змісті художньо-педагогічної освіти та дизайнерська діяльність, як засіб творчого художнього розвитку майбутніх учителів розширить межі їхньої професійної художньо-естетичної, проектної й мистецької компетентності.

\section{ЛIТЕРАТУРА}

1. Близнюк М. М. Педагогічний дизайн як сучасний дидактичний напрям у підготовці майбутніх художників / М. М. Близнюк // Науковий огляд. - № 4(47). - 2018. С. $77-89$.

2. Денисенко С. М. Педагогічний дизайн у сучасному освітньому процесі / С. М. Денисенко // Вісник Житомирського державного університету імені Івана Франка. - 2015. - Вип. 3. - С. 79-83.

3. Нагаева И. А. Педагогический дизайн и педагогическое проектирование: проблемы и перспективы / И. А. Нагаева // Информатизация и связь. - 2012. - № 4. - С. 61-64.

4. Прусак В. Ф. Становлення дизайн-освіти в Україні / В. Ф Прусак // Вісник Львівського університету. Серія педагогічна. - 2002. - Вип. 16.4.1. -С. 80-87.

5. Сидоренко В. Ф. Дизайнерские методы познания [Електронний ресурс] / В. Ф. Сидоренко. - Режим доступу: http: / www.rosdesign.com / design_materials 2/diz metod. htm.

6. Терешкун А. В. До питання дизайн-освіти в Україні: культурологічний аспект / А. В. Терешкун // Вісник Харківської державної академії дизайну і мистецтв. Мистецтвознавство. Архітектура. - 2011. №3. - С. 79-81.

7. Фурса О. О. Основні напрями і чинники становлення дизайн-освіти / О. О. Фурса // Науковий вісник НЛТУ України. - 2013. - Вип. 23.18. - С. 392-398.

8. Фурса О. О. Розвиток дизайн-освіти в Україні і зарубіжжі: історико-порівняльний аспект / О.О. Фурса // Порівняльна професійна педагогіка. -2011. - Вип. 2. -C.112-124.

9. Шевченко А. І. Методика навчання художнього проектування майбутніх фахівців 3 дизайну: дис. на здобуття наук. ступеня канд. пед. наук: 13.00.02 / Шевченко Анна Ігорівна. - Київ, 2017. - 351 с.

\section{REFERENCES}

1. Blyzniuk, M. M. (2018). Pedahohichnyi dyzain yak suchasnyi dydaktychnyi napriam u pidhotovtsi maibutnikh khudozhnykiv [Pedagogical design as a modern didactic direction in the preparation of future artists]. Naukovyi ohliad, no. 4(47), pp. 77-89. [in Ukrainian].

2. Denysenko, S. M. (2015). Pedahohichnyi dyzain u 


\section{КОЛІР-ПСИХОЛОГО-ПЕДАГОГІЧНИЙ АСПЕКТ ПРИЗОБРАЖЕННІ ЕМОЦЙНОГОСТАНУ ЛЮДИНИ, ПРИРОДИНА УРОКАХ ОБРАЗОТВОРЧОГО МИСТЕЦТВА}

suchasnomu osvitnomu protsesi [Pedagogical design in the modern educational process]. Journal of the Zhytomyr Ivan Franko State University. Vol. 3, pp. 79-83. [in Ukrainian].

3. Nagayeva, I. A. (2012). Pedagogicheskiy dizayn i pedagogicheskoye proyektirovaniye: problemy i perspektivy [Pedagogical design and pedagogical design: problems and perspectives]. Informatizatsiya i svyaz, no. 4, pp. 61-64. [in Russian].

4. Prusak, V. F. (2002). Stanovlennia dyzain-osvity v Ukraini [Becoming a design education in Ukraine]. Journal of the University of Lviv. The series is pedagogical. Vol. 16.4.1, pp. 80-87. [in Ukrainian].

5. Sidorenko, V. F. Dizaynerskie metody poznaniya [Design methods knowledge]. Available at: http: / www.rosdesign.com / design materials $2 / \mathrm{diz}$ metod. htm. [in Russian].

6. Tereshkun, A. V. (2011). Do pytannia dyzain-osvity v Ukraini: kulturolohichnyi aspect [The issue of design education in Ukraine: the cultural aspect]. Journal of the Kharkiv State Academy of Design and Arts. Art studies. Architecture, no. 3, pp. 79-81. [in Ukrainian].

7. Fursa, O. O. (2013). Osnovni napriamyi chynnyky stanovlennia dyzain-osvity [The main directions and factors of formation of design education]. Scientific Bulletin of UNFU. Vol. 23.18, pp. 392-398. [in Ukrainian].

8. Fursa, O. O. (2011). Rozvytok dyzain-osvity v Ukraini i zarubizhzhi: istoryko-porivnialnyi aspekt [Development of design education in Ukraine and abroad: historical and comparative aspect]. Porivnialna profesiina pedahohika. Vol. 2, pp. 112-124. [in Ukrainian].

9. Shevchenko, A. I. (2017). Metodyka navchannia khudozhnoho proektuvannia maibutnikh fakhivtsiv z dyzainu [Methodology for teaching artistic designing of future design specialists]. Candidate's thesis. Kyiv, $351 \mathrm{p}$. [in Ukrainian].

Стаття надійшла до редакції 31.07.2018

УДК 74.017

DOI:

Микола Пригодін, старший викладач кафедри українського декоративно-прикладного мистецтва та графіки, член Спілки дизайнерів Украӥни

Харківського національного педагогічного університету імені Г.С. Сковороди

\section{КОЛІР-ПСИХОЛОГО-ПЕДАГОГІЧНИЙ АСПЕКТ ПРИ ЗОБРАЖЕННІ ЕМОЦІЙНОГО СТАНУ ЛЮДИНИ, ПРИРОДИНА УРОКАХ ОБРАЗОТВОРЧОГО МИСТЕЦТВА}

Стаття висвітлює колір як важливий психолого-педагогічний аспект при зображенні емочійного стану людини чи передачі настроїв у природі на уроках образотворчого мистечтва в педагогічних навчальних закладах освіти. Разом з тим підкреслюється культурологічна спрямованість, де роль учителя як суб 'єкту педагогічного прочесу потребує вдосконалювати художню освіту і національні иінності на рівні європейських стандартів.

Оволодіння колірною системою, щуо відповідає художньому й естетичному вихованню учнів; вчитель допомагає їм формувати власні творчі уміння з колористики, створюючи гармонійну твору особистість.

Ключові слова: колір; ахроматичні і хроматичні фарби; образотворче мистецтво; педагогіка; художньо-естетичне виховання.

Jim. 5.

Mykola Pryhodin, Senior Lecturer of the Ukrainian Arts and Crafts and Graphics Department, Member of the Union of Designers of Ukraine Kharkiv Hryhoriy Skovoroda National Pedagogical University

\section{COLOR AS PSYCHOLOGICAL AND PEDAGOGICALASPECT IN DEPICTING THE EMOTIONAL STATE OF MAN, NATURE IN THE LESSONS OF FINE ART}

The article highlights the color as an important psycho-pedagogical aspect in depicting the emotional state of a person or transferring mood of nature in the lessons of fine art in pedagogical educational institutions of education. At the same time, the cultural orientation of the educational process is emphasized, where the role of the teacher as a subject of the pedagogical process needs to improve an artistic education and national values at the level of European standards taking into account the environment (enamel, nitrophobes) and energy saving technologies. Color is a figurative and emotional means of fine arts (graphics, painting, sculpture). In our visual representation, the color of the same subject is perceived differently, depending on the nature itself, where the colors are naturally combined and operate by three factors: the first factor is the influence of the source of illumination of objects.

The second factor - paints in nature are harmonized with the help of the interaction of reflexes, where the reflection of the color surface of one object to another object is carried out. 